Revista lus et Praxis, Año 27, № 1, 2021, pp. 121 - 142

ISSN 0717 - 2877

Universidad de Talca - Facultad de Ciencias Jurídicas y Sociales

El deber contractual de información del abogado

Sebastián Bozzo Hauri

Gonzalo Ruz Lártiga

Fecha de recepción: 2018-05-03; fecha de aceptación: 2020-07-13

\title{
El deber contractual de información del abogado*
}

THE INFORMATION DUTY OF THE LAWYER

SEBASTIÁN BOZZO HAURI ${ }^{* *}$ GONZALO RUZ LÁRTIGA***

\section{RESUMEN}

En el presente trabajo se analiza el contenido del deber de información del abogado con relación a su cliente en dos escenarios: cuando el encargo consiste en gestiones judiciales en donde el primero asume la defensa de los derechos del segundo, y, cuando los encargos consisten en gestiones no judiciales que pueden ser variados en su objeto.

\section{PALABRAS CLAVE}

Deber de información, obligaciones implícitas, mandato, prestación de servicios profesionales

\section{ABSTRACT}

In the present paper, the content of the lawyer's information duty in relation to his client is analyzed in two scenarios: when the order consists of legal proceedings in which the first assumes the defense of the rights of the second, and, when the orders consist of non-judicial procedures that can be varied in their purpose.

\section{KEYWORDS}

Duty of information, implicit obligations, mandate, provision of professional services

\section{Introducción}

Como su raíz etimológica lo indica, vocatus ad, el abogado, es llamado para asistir profesionalmente a otro en la defensa de sus derechos e intereses. Debidamente juramentado, se obliga a desempeñar leal y honradamente la profesión ${ }^{1}$, cuyos orígenes se remontarían a

\footnotetext{
* Este trabajo se enmarca dentro del proyecto de investigación DIUA107-2017 de la Vicerrectoría de Investigación y Postgrado de la Universidad Autónoma de Chile.

** Abogado, Magíster y Doctor en Derecho por la Universidad de Valencia España. Profesor de Derecho Civil Universidad Autónoma de Chile. Dirección postal: Pedro de Valdivia 641, Providencia, Santiago, Chile. Correo electrónico: sebastian.bozzo@uautonoma.cl. ${ }^{* * *}$ Abogado. Doctor en Derecho privado por la Université d'Aix-Marseille, Francia. Profesor asociado Escuela de Derecho (Santiago), Facultad de Ciencias Jurídicas y Sociales, Universidad Santo Tomás. Investigador del Instituto de Investigación en Derecho de la Universidad Autónoma de Chile. Dirección postal: Ejército 146, piso 7, Santiago. Correo electrónico: gonzaloruz@santotomas.cl.

${ }^{1}$ Artículo 522 del Código Orgánico de Tribunales.

Para LOYOLA (2013), p. 136, “... quizás el primer pueblo que vio nacer el ejercicio de la profesión a que nos avocamos fue el griego, cantera inagotable de sabiduría, dio a luz entre sus muchos personajes a Pericles quien es considerado el primero en usar la elocuencia en el ejercicio de la abogacía. Luego se introdujo la costumbre, tanto en el Areopago de Atenas cuanto en los otros tribunales de Grecia, de hacerse asistir en los juicios por oradores famosos a fin de dar más firmeza a las acusaciones o defensas planteadas; de esta forma fue Antiphon el primero que compuso, para algunos de sus conciudadanos, oraciones que ellos pronunciaban para sostener su derecho en juicio, lo mismo hicieron Lisias, Isócrates y Demóstenes, aunque muchas veces ellos mismos pronunciaban sus oraciones", añade que "en la península lbérica en principio, no se conoció del oficio masivo de defen sores (...) La regla general de la prohibición de defenderse por voceadores o letrados queda establecida en la Ley II, Título II de los 'Compenzamientos' y de los 'Pleytos' Libro II del Fuero Juzgo, en la cual se establece perentoriamente que los pleitos no deb en ser
} 
Roma bajo el reinado de Claudio $^{2}$. Directamente relacionado con las ideas de asistencia profesional, defensa judicial de derechos e intereses ajenos y colaboración en la recta administración de la justicia, la profesión de abogado, como coinciden en afirmar sociólogos y juristas, es un aporte imprescindible para la realización de la justicia y, en definitiva, para la consecución de la paz social.

Desde las expresiones más ideales donde "el sacrificio del interés particular por el interés de la justicia debe ser la ley de esta profesión (...)"3, hasta las más mundanas donde "la profesión de abogado es un tipo de industria, un medio de existencia, una de las formas de culto del interés privado" ${ }^{4}$, el ejercicio de la profesión de abogado no puede desmarcarse de esa relación de calificada confianza recíproca que marca el acuerdo de voluntades que une al abogado con el cliente. Tan cierto como que el cliente elige a su abogado es que el abogado elige a su cliente. Igualmente, cierto es que tan pronto uno deja de confiar en el otro este vínculo está condenado a su extinción. De ahí que la estabilidad del pacto que une al cliente con su abogado dependa menos de su fuerza obligatoria que del mantenimiento de la confianza recíproca que los llevó a contratar, y es precisamente en ese escenario que la información que se transmitan las partes pasa a ser determinante.

En un trabajo anterior, dedicado al deber precontractual de información del abogado, hemos podido adelantar que en la etapa de ejecución del contrato que vincula al abogado con su cliente, la obligación de información se calificará generalmente como una obligación accesoria ${ }^{5}$, más precisamente siguiendo la expresión del profesor Mekki, "una obligación periférica al servicio de la obligación principal" ${ }^{6}$, salvo en aquellos casos en que la información constituya el objeto principal de la prestación del servicio jurídico contratado. En la generalidad de los casos, la obligación de información del abogado para con su cliente no tiene consagración expresa en la ley ${ }^{7}$, de ahí su calificación como una obligación no contractual o implícita ${ }^{8}$, llevándonos a sostener que el cliente se encontraba, en cierta forma, en una situación de vulnerabilidad informacional, con relación a su abogado. La obligación de información del profesional se erige, entonces, en medio de la emergencia de una idea de solidarismo contractual ${ }^{9}$, que tiende a remediar las evidentes asimetrías de información existentes entre las partes.

\footnotetext{
estorbados por 'voces', refiriéndose a estos terceros defensores de los litigantes letrados" (pp. 137-138). En Francia, los primeros textos que reglamentan la profesión de abogado remontan al año 1274.

${ }^{2}$ APPLETON (1928), p. 25, citando a Tácito, Ann., XI, 5-7; XIII, 42; Suetonio, Neron, 17, Plinio, Epistolæ, V, 4, 14,211 y Quintiliano, Inst. Orat., XII, 7, 8, relata que los orígenes de la abogacía como profesión estarían en el episodio en el que Samius, un distinguido caballero romano se suicida en casa de su abogado después de haberse enterado que éste traicionaba sus intereses habiéndole pagado 400.000 sestercios de honorarios. El escándalo amenazaba con un edicto severo que asimilaría la recepción de honorarios al delito de concusión. Suilius y otros abogados obtuvieron del emperador el reconocimiento del derecho a vivir de la profesión, decidiendo éste que los abogados no podrían recibir más de 10.000 sestercios de sus clientes, so pena de concusión. Contra: MARTÍNEZ (1993), p. 2, para quien "la abogacía se convirtió en profesión cuando el Emperador Justino constituyó el primer colegio y obligó a su registro, en él, de cuantos fueran a abogar en el foro...". Para profundizar en la profesión de abogado en Roma: véase BARCIA (2008), pp. 183-266. En nuestro país: DE LA MAZA (2002), p. 195, revela que los estudios conducentes al título de abogado comenzaron en Chile con la fundación de la Universidad de San Felipe en 1758. Antes de ello, en la estructura jurídica del ChileIndiano, según DOUGNAC (1994), p. 152, "los abogados como auxiliares de la administración de justicia estaban regulados por el título 24 del libro $2^{\circ}$ del Rec. Ind, que recoge disposiciones de las ordenanzas de Audiencias de 1563". Para profundizar en la profesión de abogado en Chile indiano: véase GERTOSIO (2005), pp. 233-250.

${ }^{3}$ VERCHERE (1840), p. 2.

${ }^{4}$ VERCHERE (1840), p. 3.

${ }^{5}$ Por todo: véase GILSON-MAES (2016), pp. 133-147.

${ }^{6}$ MEKKI (2013), p. 83.

${ }^{7}$ A diferencia de otro profesional liberal, como el médico, donde, entre otras disposiciones, el inciso $1^{\circ}$ del artículo 10 de la Ley № 20.584, de 2013, que regula los derechos y deberes que tienen las personas en relación con acciones vinculadas a su atención en salud, prevé expresamente que: "Toda persona tiene derecho a ser informada, en forma oportuna y comprensible, por parte del médico u otro profesional tratante, acerca del estado de su salud, del posible diagnóstico de su enfermedad, de las alternativas de tratamiento disponibles para su recuperación y de los riesgos que ello pueda representar, así como del pronóstico esperado, y del proceso previsible del postoperatorio, de acuerdo con su edad y condición personal y emocional".

${ }^{8}$ Sobre la noción de obligaciones implícitas: véase FESSARD (2015); LEGRAND (1991), pp. 109-146; LYON-CAEN (2010), pp. 109-113, particularmente en la disciplina del derecho del trabajo.

9 JAMIN (2001), pp. 441 y ss. Esta idea de solidarismo contractual puede encontrarse ya, a comienzos del siglo pasado, con Raimond Saleilles que propiciaba la necesidad de renovar las reglas de interpretación de los contratos. SALEILLES (1901), p. 229, apelaba a un
} 
La inexistencia de una ley especial que regule el deber de información de los abogados conduce, entonces, a la búsqueda de esta regulación (su contenido, forma, extensión y límites), primeramente, en las reglas generales del Derecho común de los contratos y las obligaciones; luego o coetáneamente, en las normas profesionales (lex artis) y deontológicas que emanan de los órganos encargados del control ético de estos profesionales; $y$, en fin, cuando sea posible considerar que la prestación de servicios jurídicos es otorgada al cliente-consumidor por un abogado-proveedor, a las reglas contenidas en la Ley de Protección al consumidor.

La dificultad, entonces, de ofrecer un panorama sistémico de la obligación de información dice relación, más allá de la ausencia de una norma especial que la regule, con que, además, en cada una de las variadas tareas o misiones que el cliente o la ley encargan al abogado, el deber de informar varía en su contenido e intensidad.

Con todo, es posible aventurarse en entregar una contribución dogmática a partir de la observación de ciertos factores, tanto objetivos como subjetivos, que incidirán en el contenido de esta obligación de información. En los primeros, la naturaleza y objeto del encargo que se le hace al abogado y, en los segundos, los particularismos de cada parte (cliente y abogado) ${ }^{10}$ van a incidir en el contenido y la extensión de la obligación de información del abogado para con su cliente.

Sea que el cliente encargue la defensa de sus derechos y/o su representación en un juicio o contienda judicial al abogado; sea que el encargo consista en la redacción de uno o más actos o contratos en el que el primero sea autor o parte, o que el mismo consista en una asesoría o consejo que constituya el objeto esencial de la prestación, en todos estos encargos que son probablemente los más comunes e importantes que se hacen al abogado, la intensidad de la obligación de información que pesa sobre este variará en la misma forma que varía el objeto de la prestación que se le impone.

Para poder desentrañar, entonces, el contenido de la obligación de información del abogado con relación a su cliente, proponemos un análisis sobre la base una división binaria simple: por un lado, en el contexto de los encargos que consisten en gestiones judiciales, en donde el abogado asume la defensa de los derechos del cliente en juicio; $y$, por otro lado, en el contexto de aquellos encargos que consisten en gestiones no judiciales que pueden ser variados en su objeto. La primera parte se desarrollará más en extenso, de manera tal que la segunda pueda desplegarse sobre esos desarrollos sin necesidad de repeticiones odiosas e inútiles.

\section{El contenido y extensión de la obligación de información del abogado frente al encargo de defender los derechos del cliente en juicio}

El encargo de defender los derechos del cliente en juicio, por expresa disposición del artículo 528 del Código Orgánico de tribunales, es un mandato ${ }^{11}$, con la sola salvedad que no termina por la muerte del mandante, según lo prescribe el artículo siguiente. Limitándose, entonces, el citado Código a calificar de mandato el acto jurídico (continente) por el cual una persona encomienda a un abogado la defensa de sus derechos en juicio, son naturalmente a las normas que regulan este contrato especial al que habrá que remitirse, primeramente, para

\footnotetext{
proceso de interpretación que no se detuviera en la voluntad de una u otra partes, sino en la voluntad contractual, que no era la suma de ambas, sino "aquella que se deduce del contrato como lo que es o lo que hubiera debido ser (...) El contrato no es el acto de una voluntad creadora de derecho, sino el proceso de adaptación de las voluntades privadas a la utilización de los esfuerzos comunes para la satisfacción de los intereses individuales recíprocos. Así, es según el fin social de este procedimiento de solidaridad jurídica, y no según la fantasía individual de cada uno de los que de él forman parte, que el contrato debe ser interpretado y aplicado." En el mismo sentido, con anterioridad, SAINCTELETTE (1884), p. 131: "[q]ui dit contrat dit commune intention. La commune intention n'est pas divisible. Elle est ou elle n'est pas".

${ }^{10}$ La incidencia de la situación de vulnerabilidad infraccional del cliente, atendida su capacidad para comprender la información que le suministra el abogado, ha sido tratada en otro trabajo de estos mismos autores aparecido en esta Revista (Vol. 25 № 1 abr. 2019 , pp. 49-88), titulado "El deber precontractual de información del abogado".

${ }^{11}$ Art. 528 COT. "El acto por el cual una persona encomienda a un abogado la defensa de sus derechos en juicio, es un mandato, que se halla sujeto a las reglas establecidas en el Código Civil sobre los contratos de esta clase, salvo la modificación estable cida en el artículo siguiente".
} 
determinar el contenido de la obligación de información del mandatario ${ }^{12}$. Del análisis de estas disposiciones aparecen dificultades para extraer la existencia de una obligación contractual de información del abogado (2.1) y luego, al tipificarla, otras complicaciones con relación a su contenido a fin de calificarlas como obligación de medios o de resultado (2.2).

\subsection{Las dificultades para extraer del mandato una obligación de informar del abogado}

A pesar de los perentorios términos del artículo 528 del Código Orgánico de tribunales, el encargo de defender los derechos del cliente en juicio no se aviene estrictamente con el contrato de mandato regulado en el Código civil. La ausencia de regulación expresa de la obligación de información en ese contrato, el carácter liberal y profesional del abogado, la función de servicio público que cumple este como colaborador de una buena administración de justicia, el monopolio que la ley concede a los abogados en ciertas materias, la facultad de representación que subyace por la naturaleza de la profesión, y otra serie de circunstancias hacen que, en general, la calificación de mandato para el acto por el cual se encarga la defensa de los derechos del cliente en juicio no sea del todo ajustada.

\subsubsection{Los límites que presenta la regulación del mandato en el Código civil.}

El propio Código civil, al que remite el Código Orgánico de Tribunales como viene de ser dicho, no califica de mandato a los servicios profesionales que suponen largos estudios a los que está unida la facultad de representar a otro, solo señala que estos servicios se sujetarán a las reglas del dicho contrato ${ }^{13}$. Nuestros Tribunales superiores de justicia así lo han resuelto sentando la doctrina según la cual "la prestación de los servicios a que se refiere el artículo 2118 del Código civil no es técnicamente un mandato" ${ }^{14}$.

En efecto, si se revisan las reglas del mandato contenidas en el Título XXIX del Libro Cuarto del Código civil (artículos 2116 a 2173), la obligación de información que puede denominarse en palabras del Código como "obligación de dar cuenta de la administración" aparece solo en una disposición (artículo 2155) ${ }^{15}$ y ella naturalmente ha sido analizada como una obligación que nace, generalmente, al término del mandato ${ }^{16} \mathrm{y}$ concluido que ha sido el encargo.

\footnotetext{
${ }^{12}$ Antes, es preciso aclarar, como lo hace un fallo de larga data de la Excma. Corte Suprema, de 5 de julio de 1920 (C. 8으, al final, p. 150), "que el mandato para defender derechos en juicio es diverso y no se halla comprendido en el mandato para representar los mismos derechos ante los tribunales". En efecto, al primero se le denomina mandato de patrocinio y encuentra su regulación en el artículo 10 de la Ley 18.120, de 1982. El segundo es un mandato de representación para comparecer en juicio, que lo habilita para actuar en el nombre y por cuenta del mandante en cualquiera de las actuaciones, gestiones o trámites de las diversas instancias del juicio o asunto con las facultades a que se refiere el inciso 10 del artículo 70 del Código de Procedimiento civil. Este mandato puede recaer en la misma persona del abogado patrocinante o en otro abogado o habilitado de derecho, y será más amplio o especial según si se le han conferido al mandatario las facultades a que se refiere el inciso 2 o del mismo artículo y Código señalados. Ambos mandatos son específicos, solemnes y requieren que el mandatario tenga la calidad de abogado, en el primero; y, en el segundo, de abogado o habilitado de derecho. Se diferencian, en cambio, en las formas que la ley ha exigido para constituirlos y en la responsabilidad que asume el patrocinante o el apoderado en ciertos casos.

${ }^{13} \mathrm{Art.} 2118$ CC. "Los servicios de las profesiones y carreras que suponen largos estudios, o a que está unida la facultad de representar y obligar a otra persona respecto de terceros, se sujetan a las reglas del mandato."

${ }^{14}$ Corte Suprema, Rol № 5898-2012, de 28 de enero de 2013 (C. $4^{\circ}$ ). Confirmando esta doctrina judicial: Corte Suprema, Rol № 5898-2012, de 28 de enero de 2013, 1a civ.

${ }^{15}$ Art. 2155 CC. "El mandatario es obligado a dar cuenta de su administración.

Las partidas importantes de su cuenta serán documentadas si el mandante no le hubiere relevado de esta obligación.

La relevación de rendir cuentas no exonera al mandatario de los cargos que contra él justifique el mandante."

16 STITCHKIN (2008), p. 401, en donde el autor expresa esta idea: "La rendición de cuentas tiene por objeto principal poner en conocimiento del mandante la forma en que se ha llevado a efecto la gestión del negocio, los resultados del mismo y la restitución de todo lo que el mandatario ha recibido en virtud del mandato, sea del propio mandante, sea de terceros, y aun cuando lo pagado por estos no se deba al mandante, art. 2157. Así se ha fallado." Andrés Bello siguió en esta parte, según nota marginal al actual artículo 2155 en el Proyecto de 1853, el curso de derecho civil de DELVINCOURT (1819), p. 128, quien establecía como tercera obligación del mandatario la de rendir cuenta de su gestión, destacando que en ella el mandatario debía restituir al mandante todo aquello que había recibido en virtud del mandato.
} 
Sin embargo, el artículo 2155 en parte alguna permite concluir que el mandatario esté obligado a informar de su gestión solo al concluir el encargo ${ }^{17}$. Naturalmente es llamado a hacerlo en ese momento, pero no única y exclusivamente ahí. Otras disposiciones del Código en el Título XXIX permitirían concluir lo contrario en caso de que, como es recurrente, no se encuentre escriturado o previsto en el pacto la obligación de informar durante el desarrollo del encargo. Como fuere, y advirtiendo que no profundizaremos en las distintas respuestas para dar con la naturaleza jurídica del contrato que une al abogado con su cliente ${ }^{18}$, por exceder los objetivos de esta contribución, partiremos del supuesto legal y su calificación como mandato.

En general es habitual que en el mandato que une al cliente con su abogado no se estipulen los términos específicos a los cuales deba ceñirse rigurosamente la gestión del mandatario, pues difícilmente un lego podrá instruir a un profesional sobre las reglas de su lex artis. Lo anterior, sin embargo, no le permite tampoco al mandatario obrar del modo que mejor le parezca sin consultar al mandante estando en situación de poder hacerlo. En concreto, y, por un lado, para obrar del modo que más conveniente le parezca se requiere cláusula especial (artículo 2133$)^{19} y$, por otro lado, estando el abogado en situación de poder consultar al cliente debe hacerlo en caso de no haberse especificado las instrucciones (artículo 2148) ${ }^{20}$. La consulta al mandante supone, evidentemente, informarle previamente de aquello que causa la consulta.

Esta conclusión se encuentra en armonía, en el orden deontológico, con lo regulado en el Código de Ética profesional del Colegio de abogados de Chile en dos disposiciones. Por la primera, el artículo 28, el abogado asume, principalmente, el deber ético de "mantener informado al cliente, en forma veraz, completa y oportuna del estado del encargo profesional encomendado, $y$, de manera especial, de todo asunto importante que surja en su desarrollo"; por la segunda, el artículo 29, se regula el deber de información en relación a la obligación de actuar conforme a las instrucciones, disponiendo que "el abogado debe actuar conforme con las instrucciones recibidas por el cliente, cuidando que éste haya sido informado de conformidad con el artículo precedente".

En ese mismo orden de cosas, la disciplina del derecho procesal civil, comprueba directa o indirectamente la existencia de una obligación de información, como cuando este estatuto impone cargas y actuaciones procesales a la parte, respecto de las cuales el abogado debe actuar conforme a las instrucciones que de esta, su cliente, reciba, lo que implica evidentemente noticiarla o informarla previamente, independientemente de si ha recibido del cliente o de la ley el mandato de representarla en todas las instancias del juicio. Así, entre otros, los derechos por los servicios prestados en el proceso por los oficiales de la administración de justicia son una carga que corresponde asumir al cliente ${ }^{21}$, imponiendo la ley una obligación solidaria a los procuradores judiciales para concurrir a su pago, sin perjuicio de la responsabilidad del mandante ${ }^{22}$; igualmente deberá informar el abogado al cliente cuando el juez solicite la concurrencia personal de este último a una audiencia de conciliación ${ }^{23}$; asimismo el procurador judicial se obliga a hacer comparecer a su mandante para absolver posiciones en el juicio ${ }^{24}$, lo

\footnotetext{
${ }^{17}$ Así lo ha confirmado un fallo de larga data de la Excma. Corte Suprema, de 22 de junio de 1906 (C. 40, p. 647), sentando la doctrina según la cual: "la rendición de cuentas tiene lugar no solo a la terminación del mandato, sino en todo momento en que la ejecución de uno o más de los encargos hechos al mandatario o el curso progresivo de las gestiones que se le hubieren encomendado la haga necesaria. De otro modo dependería con frecuencia el cumplimiento de la obligación del mero arbitrio del obligado, o se pondría en manos de éste el medio de retardar sin término su cumplimiento, reteniendo arbitrariamente los bienes del mandante".

18 Para este efecto proponemos la lectura de: BRANTT y MEJÍAS (2016), pp. 71-103; BARROS (2012), pp. 326-329; RODRÍGUEZ (2008), pp. 503-517, entre otros.

${ }^{19}$ Art. 2133 CC. "Cuando se da al mandatario la facultad de obrar del modo que más conveniente le parezca, no por eso se entenderá autorizado para alterar la substancia del mandato, ni para los actos que exigen poderes o cláusulas especiales.

Por la cláusula de libre administración se entenderá solamente que el mandatario tiene la facultad de ejecutar aquellos actos que las leyes designan como autorizados por dicha cláusula".

${ }^{20}$ Art. 2148 CC. "Las facultades concedidas al mandatario se interpretarán con alguna más latitud, cuando no está en situación de poder consultar al mandante".

${ }^{21}$ Artículo 25 del Código de Procedimiento Civil.

${ }^{22}$ Artículo 28 CPC. "Los procuradores judiciales responderán personalmente del pago de las costas procesales generadas durante el ejercicio de sus funciones, que sean de cargo de sus mandantes, sin perjuicio de la responsabilidad de estos".

${ }^{23}$ Artículo 264 del Código de Procedimiento Civil.

${ }^{24}$ Artículo 398 del Código de Procedimiento Civil.
} 
que naturalmente exige informarle sobre ello y ponerle en antecedentes de las consecuencias de no concurrir o de concurrir y dar respuestas evasivas ${ }^{25}$. En el orden recursivo, al igual que en Francia, en España el Tribunal Supremo ha podido hacer responsable civilmente al abogado que no ha informado al cliente la posibilidad de recurrir de una sentencia ${ }^{26}$; o por no haberle informado del plazo de que disponía para consignar el precio aplazado evitando la resolución de la venta y la pérdida de inmueble ${ }^{27}$, entre otras.

En síntesis, sin ser un negocio fiduciario ${ }^{28}$, sino una vinculación jurídica doblemente de confianza, pues el mandato es un contrato intuito persona y, además, es un contrato concluido en consideración de la persona ${ }^{29}$ del otro contratante, lo cierto es que la obligación de informar no tiene consagración expresa en la letra de la ley. Sin embargo, su fundamento es posible encontrarlo en deberes fiduciarios reforzados, propios de vínculos de esta naturaleza, como la buena fe o lealtad, particularmente, porque destaca en este contrato que los intereses de las partes no son antagónicos, sino más bien convergentes, lo que explica el deber de colaboración que debe reinar a todo lo largo de su ejecución y la primacía del principio del interés del mandante por sobre el del mandatario ${ }^{30}$.

No apareciendo, entonces, en las reglas del mandato contenidas en el Código civil u otras leyes especiales ${ }^{31}$ la obligación explícita del mandatario de informar a su mandante durante el desarrollo del encargo efectuado, hace que, natural y lógicamente, se analice esta como una obligación implícita, de aquellas que conforme al artículo 1546 del Código civil, se integra al contrato, pues se trata de "cosas que emanan precisamente de la naturaleza de la obligación, o que por la ley o la costumbre pertenecen a ella".

\subsubsection{El recurso a la noción de obligaciones implícitas}

Josserand diagnosticaba, a comienzos del siglo XX, un "crecimiento del dinamismo contractual" 32 lo que se traducía, cualitativamente, en la amplificación del contenido obligacional del pacto $y$, cuantitativamente, en la multiplicación y diversificación de los contratos $^{33}$. La ampliación del contenido obligacional se producía por lo que él denominaría obligaciones jurisprudenciales o pretorianas y que, actualmente, hay consenso en denominar obligaciones implícitas o no materializadas en el contrato.

La noción de obligaciones implícitas o no materializadas en el contrato demuestra que, independientemente de la existencia o no de un instrumentum en que este se apoye, ciertas

\footnotetext{
${ }^{25}$ Artículos 393 y 394 del Código de Procedimiento Civil.

${ }^{26}$ STS, 14 diciembre 2005, RJ 2006, p. 1225. En el fundamento 4ㅇ de esta sentencia se puede leer el razonamiento del sentenciador español: "Cierto es que la decisión de recurrir no corresponde al Letrado sino a su cliente y que para que ello tenga adecuada efectividad se le debe comunicar el resultado del juicio, traducido en este caso en una sentencia parcialmente estimatoria de sus pretensiones. No lo hizo así por evidentes y unilaterales razones que no encuentran justificación alguna desde la idea de que no consta que fuera esa la intención de su cliente y de que, si entendía inviable el recurso, debió comunicárselo con antelación suficiente para que pudiera adoptar la solución procesal más conveniente a su derecho. Esta falta de diligencia privó al actor de toda p osibilidad de impugnar eficazmente la sentencia de instancia, y ello se traduce en un incumplimiento contractual culposo generador de un perjuicio que ha de ser reparado. Se reitera que no se trata de que el Abogado haya de garantizar un resultado favorable a las pretensiones de la persona cuya defensa asumió, si no de que ponga en disposición de su cliente todos los conocimientos, la diligencia y la prudencia que se esperan de un profesional del derecho, y que en condiciones normales debería haber hecho, como es la formulación y personación en forma para sostener el recurso de apelación." En Francia se consagra expresamente este deber de información en el caso del abogado ad litem en el artículo 412 del Código de procedimiento civil que dispone: "La mission d'assistance en justice emporte pouvoir et devoir de conseiller la partie et de présenter sa défense sans l'obliger".

${ }^{27}$ STS, 18 de febrero de 2005, RJ 2005, p.1682.

${ }^{28}$ FUEYO (2010), pp. 865-884.

29 Para una distinción neta de ambas nociones: véase Cass. Com., 29 de enero de 2013, Pourvoi N 11-23676.

${ }^{30}$ Así lo confirma el artículo 3o del Código de Ética profesional del abogado. "Lealtad con el cliente y respeto por su autonomía. El abogado debe obrar siempre en el mejor interés de su cliente y anteponer dicho interés al de cualquier otra persona, incluyen do al suyo propio. En el cumplimiento de este deber el abogado debe respetar la autonomía y dignidad de su cliente. El deber de lealtad del abogado no tiene otros límites que el respeto a la ley y a las reglas de este Código".

${ }^{31}$ Código Orgánico de Tribunales, Código de Procedimiento Civil, Ley 18.120, etc.

32 JOSSERAND (1937), pp. 1 y ss.

33 JOSSERAND (1934), pp. 333-346.
} 
promesas cuyo contenido no consta por escrito y que por lo mismo no nacen de la voluntad explícita de los contratantes de someterse a ellas son, sin embargo, impuestas igualmente y con la misma fuerza a las partes.

Han sido ampliamente reconocidas por la doctrina ${ }^{34}$, la jurisprudencia, tanto chilena ${ }^{35}$ como extranjera ${ }^{36}, \mathrm{y}$, expresamente, además, consagradas por instrumentos de soft la $w^{37}$.

Existe relativo consenso en la doctrina en orden a introducir con prudencia la existencia de estas obligaciones que las partes no han convenido integrar expresa y literalmente al pacto, a fin de no abrir el abanico de revisiones e intervenciones judiciales innecesarias al contrato. En efecto, la obligación implícita la descubre el juez, deduciéndola ya sea de elementos intrínsecos al pacto, como la intención de las partes; ya sea de elementos extrínsecos o exteriores a él, como su naturaleza, la costumbre, la ley, su fin económico o la buena fe, esta última el principal estándar jurídico generador de obligaciones implícitas. El objetivo final de estos elementos exteriores es, integrando las lagunas que el pacto pueda contener, poner la voluntad de las partes al servicio del fin contractual. El conjunto de obligaciones implícitas que descubre el juez y que pasan a integrar el pacto sirven, entonces, para determinar el contenido obligacional del contrato.

En ese orden de cosas, parece no solo comandado por la regla de la ejecución de buena fe del contrato, sino que, además, por la naturaleza misma del vínculo de especial o calificada confianza que se revela en el mandato que une cliente a abogado, que la obligación de información del letrado para con su cliente constituya una obligación implícita, propia o inherente a este. En la mayoría de los casos, esta obligación de informar se revelará como una obligación secundaria o accesoria, mientras en otros, los menos, será principal, cuando el objeto mismo de la prestación del servicio contratado sea precisamente la información que debe suministrarse al cliente.

Ciertamente que se presentarán dificultades al analizar el contenido, extensión o intensidad de la información que debe entregar el abogado a su cliente. Sin embargo, un mínimum o estándar razonable exigible al letrado puede extraerse del artículo 28 del Código de ética profesional del Colegio de abogados de Chile, según el cual "el abogado debe informar sobre los riesgos y alternativas de acción de modo que el cliente se encuentre en condiciones

\footnotetext{
${ }^{34}$ Véase (n. 6).

${ }^{35}$ Corte de Apelaciones de Antofagasta, Rol № 204-2014, de 23 de septiembre de 2014, revocando la sentencia de primer grado, condena a la obligación de indemnizar perjuicios al abogado que no realiza gestiones útiles en el juicio respecto del cual se le confiere mandato por el cliente, provocando la declaración de abandono del procedimiento. Lo interesante de este fallo es que da por probada la inejecución de la obligación de información del abogado, la que considera una tercera obligación implícita en el contrato que liga al cliente con el abogado (la primera es perseguir el término del juicio mediante sentencia definitiva y la segunda analizar y estudiar los antecedentes y pruebas antes de asumir el mandato). Vale la pena transcribir el considerando $6^{\circ}$ donde se expresa que: “(...) Además, si se tiene presente que artículo 1546 del Código Civil dispone que, los contratos deben ejecutarse de buena fe y por consiguiente obligan no solo a lo que en ellos se expresa, sino a todas las cosas que emanan precisamente de la naturaleza de la obligación, o que por la ley o la costumbre pertenecen a ella, pacíficamente debe aceptarse que el mandatario, demandado en autos, debió cumplir, como mínimo, tres obligaciones básicas (...) Además que informara debida, veraz y oportunamente a sus clientes respecto de la marcha el juicio y, con mayor razón aún, de sus resultados. (...) También debe convenirse que el demandado incumplió la obligación de informar oportunamente a sus clientes. Desde luego él mismo reconoce que no mantuvo comunicación con el demandante de estos autos señor George Páez, asumiendo que el otro de sus clientes ejercía una suerte de representación. Pero, además, de ser cierta la versión que dio al contestar la demanda, debiera asumirse que solo tuvo noticia del término del proceso por la declaración de abandono del procedimiento ejecutoriada en el año 2011, esto es, aproximadamente cuatro años después de su terminación, y todavía más que se enteró por los dichos de otro de sus clientes, lo que no es sino demostración de una falta de cuidado y esmero en el negocio encomendado que solo puede concluirse en el incumplimiento del mismo". En materia laboral, a modo de ejemplo: véase Corte de Apelaciones de Temuco, Rol № 88/2017, de 31 de mayo de 2017; Corte de Apelaciones de Chillán, Rol № 12/2015, de 6 de abril de 2015.

${ }^{36}$ En Francia, por ejemplo, en materia de obligación de información en la compraventa: Cass. Civ. 3a , 15 de noviembre de 2000. Consagrando una obligación de cooperación: Cass. Com., 3 de noviembre de 1992. Consagrando una obligación de renegociación: Cass. Civ. 1ạ, 16 mars 2004. Consagrando una obligación de competencia del abogado: Cass, Civ. 1ạ , 14 de mayo de 2009. En Canadá en materia de franquicia: CA Québec, Provigo Distribution inc. c. Supermarché A.R.G. inc., [1998] R.J.Q. 47 y Dunkin's Brands Canada Ltd. c. Bertico inc., 2015 QCCA 624.

${ }^{37}$ Artículo 5:1:2 de los principios UNIDROIT: "Las obligaciones implícitas pueden derivarse de: (a) la naturaleza y la finalidad del contrato; (b) las prácticas establecidas entre las partes y los usos; (c) la buena fe y la lealtad negocial. (d) el sentido común.". El artículo 6:102 de los Principios de Derecho Europeo de los Contratos: "Términos implícitos. Junto a cláusulas expresas, un contrato puede contener cláusulas implícitas que derivan de: a) La intención de las partes; b) La naturaleza y el objeto del contrato; c) y la buena fe".
} 
de evaluarlos sin hacerse falsas expectativas. El abogado debe mantener informado al cliente, en forma veraz, completa y oportuna del estado del encargo profesional encomendado, y, de manera especial, de todo asunto importante que surja en su desarrollo. Falta a la ética profesional el abogado que oculta o retrasa información al cliente o le hace declaraciones falsas o incompletas acerca del estado de las gestiones que tiene a su cargo. El abogado debe responder prontamente a las solicitudes razonables de información del cliente".

Como se advierte la obligación de información del abogado podría configurarse, en cuanto a su contenido, oportunidad y extensión, sobre estas reglas deontológicas básicas. Encargado de la defensa de los derechos del cliente en juicio, el abogado, debe, con relación al contenido de la información, noticiar de los avances del juicio, esto es, de la apertura y clausura de las distintas etapas del proceso y, particularmente, de todo asunto importante que en él surja. Con relación a la oportunidad en que debe entregarse esta información, el abogado debe asumir un rol activo en la entrega (sin esperar ser requerido para ello) y en ese contexto, cabe de suyo que esta debe ser hecha en el momento necesario o indispensable, es decir, en la época en que esta resulte útil de ser conocida a fin de tomar a tiempo las decisiones adecuadas. Pasivamente, frente a un requerimiento de información del cliente, la misma exigencia de oportunidad debe observarse, respondiendo prontamente a las solicitudes razonables de información del cliente. En fin, con relación a su extensión, la información entregada debe ser completa, entendiendo por ello, aquella que transmite al cliente todo lo necesario, de manera exacta y apegada a la verdad, para poder tomar una decisión con conocimiento de causa, previniéndole de sus consecuencias y asegurándose que esta información haya sido comprendida por él.

\subsection{Las dificultades para tipificar la obligación de información del abogado: ¿Obligación de medios o de resultado?}

Si el objeto principal del encargo, esto es, la defensa de los intereses del cliente en juicio no compromete, por regla general, la obtención de un resultado concreto, lo que hace que haya relativo consenso en que se trata de una obligación de medios, tratándose de la obligación de información sobre las gestiones relacionadas a este encargo, se presentan no pocas dificultades para adaptarla a esta tipología.

\subsubsection{El objeto principal del encargo, la defensa de los intereses del cliente en juicio no compromete, por regla general, la obtención de un resultado concreto}

Aplicando la célebre tipología de Demogue ${ }^{38}$, el abogado no asume para con el cliente cuando defiende sus derechos en juicio la obtención de un resultado determinado. Demogue,

\footnotetext{
${ }^{38}$ DEMOGUE (1925), p. 538. Este gran jurista francés fue claro, aun cuando ello no haya sido suficientemente revelado, que su contribución dogmática iba dirigida a solucionar una cuestión de prueba que tenía enfrascados a Charles Sainctelette (De la responsabilité et de la garantie, Bruxelles, Bruylant, 1884) y Jean Grandmoulin, (De l'unité de la responsabilité ou nature délictuelle de la responsabilité pour violation des obligations contractuelles, Rennes, Typographie Alphonse Roy, 1892), partidarios de una concepción dualista o monista de la responsabilidad civil, respectivamente. Esta cuestión consistía en determinar a quién correspondía la carga de probar los elementos de la responsabilidad civil. Para bien aplicar su tipología, en sede contractual, había que determinar si el objeto de la prestación del deudor consistía en la obtención de un resultado concreto o no. Así, si el deudor se obligaba a alcanzar un resultado concreto, su obligación era de resultado, la culpa se integraba al incumplimiento (exonerando al acreedor de probarla) y admitiendo para eximir de culpa al deudor solo la prueba del caso fortuito o la fuerza mayor. Si no se prometía un resultado, el deudor podía eximirse probando la ausencia de culpa, es decir, que empleó la diligencia exigida convencional o legalmente o que actúo con la debida prudencia para alcanzar el resultado no prometido, pero que, a pesar de ello, no lo logró. Para profundizar sobre la contribución dogmática de Demogue: véase MEKKI (2013), pp. 77-88. En Chile, en términos amplios se han referido a la tipología de obligaciones de medio y de resultados: PEÑAILILLO (2003), pp. 338 y ss.; BARROS (2006), pp. 657 y ss.; TAPIA (2003), p. 75; PIZARRO (2008), p. 255; DOMínGUEZ (2010), pp. 21 y ss., entre otros. Para Peñailillo en “las obligaciones de medio, el deudor compromete la realización de una conducta o actividad que debe sujetarse a las reglas de una determinada ciencia, arte o técnica, sin garantizar un resultado en particular al acreedor, cuyo interés resulta satisfecho por el solo despliegue de la referida conducta, que agota el contenido de la prestación" (p. 223).
} 
sirviéndose de un postulado de $\mathrm{Gabba}^{39}$, señalaba que "el profesional que tiene una profesión liberal, es decir, actuando con independencia en la ejecución como el médico o el abogado, no tiene a su cargo sino una obligación de medios" 40 .

La evolución de la jurisprudencia y la doctrina, particularmente en Francia, ha permitido, al igual que en materia de responsabilidad civil médica ${ }^{41}$, morigerar esta aseveración e ir descubriendo obligaciones de resultado para los abogados ${ }^{42}$. Sin embargo, es indiscutible que, mirado desde la perspectiva del objeto genérico del encargo de defender los derechos del cliente en juicio, el abogado no está obligado, por ejemplo, a ganar el pleito, obteniendo una sentencia definitiva que acoja las pretensiones del cliente o, en sentido contrario, a obtener que este no sea condenado al pago de una suma de dinero que le es reclamada, por citar solo dos situaciones precisas, sino que a hacer lo posible, a poner en ejecución todos los medios propios de la lex artis, a desplegar toda su diligencia en la ejecución de sus obligaciones para alcanzar ese resultado que no puede claramente garantizar ni prometer.

Sin embargo, la calificación de obligación de medios dependerá de lo que hubiere prometido el abogado ${ }^{43}$ y de lo que razonablemente el cliente podía esperar del contrato.

Como bien señalaba Demogue au lieu de promettre un résultat, on peut être obligé légalement ou conventionnellement de prendre certaines mesures qui normalement sont de nature à amener un résultat, esto es, que, aunque no prometamos un resultado, sí podemos obligarnos por la ley o el contrato a realizar ciertos actos que normal y razonablemente nos llevarían a alcanzar ese resultado.

Aunque la distinción ha sido y sigue siendo compleja de analizar, lo que puede extraerse de esta expresión del jurista francés es que, aunque el objeto de la prestación no sea un resultado determinado, hay una serie de medios que debe desplegar el deudor que sí pueden ser medidos por su resultado. Si el abogado no se obliga a un resultado determinado (ganar el pleito), si se obliga, por ejemplo, a evacuar diligente y oportunamente los escritos fundamentales del período de discusión ${ }^{44}$, o a rendir las pruebas en el término probatorio, o a recurrir contra las resoluciones que le causen agravio al cliente, o a concurrir a las audiencias

\footnotetext{
${ }^{39}$ GABBA (1912), p. 290, sostenía que "en todos los contratos relativos a la prestación de servicios de una persona experta, sea que conciernan la persona o la cosa, la obligación no es propiamente hablando contractual. El contrato da simplemente la posibilidad de emplear la libertad de una forma determinada, de manera que, si se hace un mal uso de ella, habría falta aquiliana". ${ }^{40}$ DEMOGUE (1925), p. 544.

${ }^{41}$ En Francia desde el famoso arrêt Mercier de 20 de mayo de 1936, la Corte de Casación considera que el médico asume una obligación de medios. Un segundo paso puede encontrarse con el denominado arrêt Bonicci de 21 de mayo de 1996, que establece una presunción de culpa en caso de infecciones nosocomiales o intrahospitalarias, correspondiéndole al centro de salud probar la ausencia de culpa. Un paso más se da el 29 de junio de 1999, en 3 fallos llamados "estafilococo dorados", en donde la Corte de Casación determina que los establecimientos de salud tienen una "obligación de seguridad de resultado" frente a estas enfermedades nosocomiales. A fines de ese mismo año (9 de noviembre de 1999), dispone la Corte de Casación que los médicos tienen una obligación de seguridad de resultado con relación a los productos que emplean en sus actos médicos, dejando a salvo el recurso del facultativo contra el productor del mismo. En Bélgica, la Corte de Apelaciones de Liège en fallo de 2008, confirmado por la Corte de Casación en 2010, condena al médico encargado de ligar las trompas de la paciente que al cabo de un tiempo se embaraza por infringir una obligación de resultado.

${ }^{42}$ La jurisprudencia francesa reconoce que el dominio de las reglas de procedimiento y, más generalmente, el conocimiento y la realización de las diligencias útiles y necesarias, son una expectativa legítima del cliente. Así, por ejemplo, sanciona imputándole directamente la culpa al abogado que no concurre a una audiencia o no deduce apelación conforme a las instrucciones del cliente (Cass. Civ. 1a 16 de enero de 2013, pourvoi № 12-14.439), aunque no lo sanciona si el recurso era inoperante (Cass. Civ. 1a, 28 de octubre de 2015, Pourvoi $n^{\circ} 14-24616$ ). En general, la Corte de Casación se muestra severa respecto del abogado en orden a exigirle que cumpla los actos de procedimiento en la forma debida y dentro de los plazos legales; que informe al cliente la existencia de recursos, plazos y formalidades para reclamar contra las resoluciones judiciales, y que efectúe todos los trámites y gestiones para preservar los derechos de los clientes. La violación de todas estas obligaciones que califica como de resultado, son susceptibles de comprometer su responsabilidad civil. Véase CASEAU-ROCHE y WITTMANN (2014), pp. 312 y ss. La Corte precisa desde 2009 (Cass. Civ. 1a 14 de mayo de 2009) que el abogado es obligado a cumplir, respetando las reglas deontológicas, todas las diligencias útiles a la defensa de los intereses de su cliente, para lo cual está investido de un deber de competencia. La jurisprudencia constante de la Corte francesa, en todo caso, es la de mantener que, en general, el abogado es deudor de una obligación de medios con relación a la acción judicial de su cliente (Cass. Civ. 1ä 7 de octubre 1998, Bull. civ. I, n² 282).

${ }^{43}$ El artículo 12 letra a) del Código de Ética profesional del Colegio de abogados de Chile, prohíbe, particular: "prometer resultados que no dependan exclusivamente de su desempeño profesional". De ahí que una promesa de este tipo sea contraria a las reglas deontológicas de la profesión.

${ }^{44}$ Para un caso en que se condena a la aseguradora encargada de la defensa del asegurado, que nombra a un abogado para ese efecto, abogado que contesta la demanda extemporáneamente y a consecuencia de ello se condena al asegurado: Véase Corte Suprema, Rol № 16.929-2016, de 30 de noviembre de 2016, "STP Santiago S.A. con RSA Seguros Chile S.A.".
} 
verbales del juicio, o a realizar gestiones útiles a fin de impedir la declaración de abandono del procedimiento, entre varias otras, y estas obligaciones, precisamente, pueden medirse por un resultado determinado. En concreto, el abogado puede argumentar que no se obligó a ganar el juicio, pero el cliente puede reclamar la ausencia de resultados en la evaluación de los medios empleados, como indicios que permitirán configurar la responsabilidad civil del profesional ${ }^{45}$. La suma de obligaciones de resultado que llamaremos "intermedias" no convierten, sin embargo, al objeto de la prestación del letrado en una promesa de resultado concreto. Así, por lo demás, aparece concebido en las reglas éticas que propone el colegio de la orden ${ }^{46}$.

Advertimos que lo que viene de ser dicho se entiende predominantemente con relación al juicio o gestión judicial contenciosa que se le encarga al abogado, en donde existe un alea o incertidumbre de que la pretensión del cliente sea acogida o no por el tribunal. Cuando el encargo judicial, en cambio, se hace para la realización de una gestión no contenciosa o voluntaria (una autorización para enajenar o contraer segundas nupcias, un inventario solemne, la dación u otorgamiento de la posesión efectiva cuando proceda en sede judicial, etc.) la prestación del letrado puede calificarse perfectamente como una promesa de resultado concreto.

La cuestión delicada que se presenta, entonces, es la de adaptar esta distinción dogmática ahora a la obligación de información del abogado que recibe el encargo de defender los derechos de su cliente en juicio.

\subsubsection{Las dificultades para adaptar la obligación de información del abogado a una obligación de medios o de resultado}

Hemos señalado que la obligación de información del abogado a quien se le encarga la defensa de los derechos del cliente en juicio se aviene mal con la clasificación demogueana. Su utilidad, como ha quedado dicho, radica en la determinación de la parte a quien le corresponderá el peso de la prueba de su inejecución o defectuosa ejecución. Su fundamento, en cambio, va más allá que la invocación de la regla de la buena fe en la ejecución de los contratos y ello es lo que provoca la falta de consenso en orden a adscribir la obligación de información del abogado en algunos de estos moldes.

En Francia la cuestión está lejos de ser resuelta por la doctrina. En efecto, el fundamento de esta obligación de información y la justificación de la intervención del juez estaría, para algunos, en un desequilibrio contractual que se produciría por la asimetría de información que se da en la relación profesional-consumidor, o más ampliamente como señalan los profesores Viney y Jourdain en la relación profesional-particular ${ }^{47}$, extensible, por cierto, a la relación

\footnotetext{
${ }^{45}$ Lo anterior permite, ciertamente, una serie de traslados de la carga probatoria. El cliente debe probar la culpa del abogado, y para ello se valdrá de ciertos resultados no alcanzados por el profesional. Así frente a la no presentación de un escrito esencial, a una alegación o defensa extemporánea, a una omisión de recurrir en tiempo y forma de una resolución agraviante o a la no presentación en estrados para alegar un recurso, no podrá el abogado excusarme que empleó todos los medios para poder hacerlo y que a pesar de ello no le fue posible. La razón está en que esas obligaciones son de resultado y solo le estará permitido excusar su culpa probando la ocurrencia de caso fortuito o fuerza mayor.

${ }^{46}$ Artículo 99 Código de Ética profesional del Colegio de abogados. "Empeño y eficacia en la litigación. El abogado responsable de representar los intereses de parte en un litigio preparará y ejecutará su encargo con el empeño y eficacia requeridos para la adecuada tutela de los intereses de su cliente. Este deber no supone lograr determinados resultados, sino poner al servicio de su cliente las competencias y dedicación profesionales requeridas por las circunstancias. Así, en el desempeño de sus funciones, el abogado debe:

a) preparar sus actuaciones de manera razonada y diligente, informándose de los antecedentes de hecho y de derecho relevantes en el caso;

b) ejecutar de manera oportuna y adecuada las actuaciones requeridas para la tutela de los intereses del cliente;

c) abstenerse de delegar tareas propias de la función de abogado en personas que no se encuentren suficientemente calificadas para su correcta ejecución".

${ }^{47}$ VINEY y JOURDAIN (2006), p. 540, quienes señalan que "se ha permitido remarcar que la obligación de información está destinada a restablecer la igualdad entre los contratantes que están precisamente en una situación de desigualdad manifiesta. Su objeto consiste en efecto a menudo en proteger a los particulares contra los profesionales más advertidos".
} 
abogado-cliente ${ }^{48}$. Esta suerte de desigualdad entre las partes, según estos autores, a la cual pondría remedio la información, justificaría la calificación de esta obligación de informar como una obligación de resultado ${ }^{49}$. La regla general, sin embargo, es que la doctrina y la jurisprudencia francesa, tienden a calificar preferentemente la obligación de información como obligación de medios ${ }^{50}$. Otros, en cambio, como la profesora Fabre-Magnan, combinarán ambas calificaciones, considerando como obligación de medios al objeto de la información, su carácter exacto y pertinente, $y$, de resultados, al hecho material de entregar la información a su destinario ${ }^{51}$.

La dificultad, en concreto para calificarla de medios o de resultados reside, según las conclusiones del profesor Mekki, precisamente "en el hecho que la obligación de información no es propiamente hablando una obligación nacida del contrato. Fuera de los contratos de asesoría o conseil donde la información es el objeto de la prestación, la obligación impuesta por la ley o el juez es una obligación periférica al servicio de la obligación principal. Ella debiera mantenerse fuera de la distinción entre obligaciones de medio o de resultado" 52 .

Podría concluirse, entonces, de todo lo que viene de ser dicho lo siguiente: La obligación de información del abogado para con su cliente, cuando aquel asume la defensa de los derechos de este en juicio, es bastante más extensa y compleja, en cuanto a su contenido, oportunidad y extensión, que la simple obligación de rendir cuenta al término del encargo, única obligación explícita de información que contiene el contrato de mandato. Dado su reconocimiento como obligación implícita y precisamente por ello, este reconocimiento dificulta, a su vez, su tipificación abstracta como obligación de medios o de resultados, lo que hace que cada una de las expresiones o manifestaciones de la información debida por el abogado al cliente no pueda ser analizada sino caso a caso, considerando, por cierto, lo que hubiere prometido el abogado y la expectativa legítima que espera el cliente de ese encargo.

Si el camino para llegar a estas conclusiones ha sido complejo, resta saber si estas complejidades subsistirán a la hora de determinar el contenido, oportunidad y extensión de la obligación de información del abogado cuando asume el encargo de defender los intereses del cliente frente a encargos no judiciales.

\section{El contenido y extensión de la obligación de información del abogado frente a encargos no judiciales}

Ya hemos avanzado que las tareas encomendadas al abogado en el ejercicio liberal de la profesión pueden ser múltiples: desde aquellas en las que el Estado le entrega un monopolio legal (la representación ad litem o judicial) hasta aquellas en las que, sin tenerlo, en los hechos y como consecuencia de la formación jurídica que posee, las monopoliza, como cuando, por una parte, el objeto del encargo sea, precisamente, informar simplemente o calificadamente, aconsejando al cliente (3.2) o, por la otra, redactar determinados actos jurídicos donde este sea su autor o parte (3.1). Evidentemente no son estas todas las "misiones" que asume el abogado en el ejercicio de la profesión, sin embargo, son las más comunes o importantes. A ambas nos

\footnotetext{
48 SARMIENTO (2012), p. 231, invocando a Dari Mattiaci y Houtcieff señala que estos "sostienen que la sociedad obtiene ventajas del intercambio de bienes y servicios que se logra a través de los contratos, lo que justifica la intervención del legislador en el control de la transmisión de información entre las partes y de las consecuencias de proporcionar información falsa relacionada con la validez del contrato. Con ello, ubican estos autores a nuestro tema en el contexto de la asimetría de la información: para que el mercado funcione correctamente debe abatirse la asimetría en la información y esto se logra a través del sistema jurídico."

${ }^{49}$ VINEY y JOURDAIN (2006), p. 540.

50 VINEY y JOURDAIN (2006), p. 540. Los autores citan la doctrina de profesores como Savatier, Alisse, Boyer y Veaux, para confirmarlo.

${ }^{51}$ FABRE-MAGNAN (1992), p. 402. Para esta autora la obligación de información, "comprende, en realidad, dos obligaciones: por una parte, una obligación de resultado, la de transmitir una información al acreedor; y por la otra, una obligación de medios, la de utilizar los medios adecuados de transmisión de la información de manera que el destinatario la reciba y la comprenda. No comprende, por el contrario, la obligación del acreedor de utilizar correctamente la información que ha recibido y comprendido" (p. 409).

52 MEKKI (2013), p. 82.
} 
referiremos a continuación, sintetizando sobre la base de algunas conclusiones ya extraídas en la primera parte.

\subsection{El encargo de redactar uno o más actos o contratos en el que el cliente sea autor o parte}

Para la redacción de la mayoría de los actos o contratos, la ley no le ha entregado al abogado el mismo monopolio que cuando se le encargan las defensas de derechos en juicio. Sin embargo, como consecuencia de la formación jurídica que posee, en los hechos, como se ha dicho, el abogado monopoliza estos encargos. Excepcionalmente, para la redacción de ciertos actos o contratos, cuando estos deban ser otorgados por escritura pública, la ley exige que las minutas sean firmadas por el abogado redactor, aunque la misma norma (artículo 413 del Código Orgánico de Tribunales) ${ }^{53}$ aclara que la omisión de esta exigencia no afectará la validez de la escritura. Actos relevantes como el otorgamiento de un testamento, la escrituración de una compraventa de un inmueble, la cesión de derechos litigiosos, el otorgamiento de cauciones reales, y tantos otros que igualmente requieren para su existencia o validez la observación de formas solemnes, no exigen, sin embargo, necesariamente, la participación de abogados en su redacción, aunque en los hechos, reiteramos, serán redactados por estos.

El encargo de redactar, entonces, uno o más actos o contratos en que el cliente tenga interés, no debiera presentar las mismas dificultades anteriormente observadas para ser calificado de mandato, sin embargo, precisamente por las limitaciones ya señaladas de esta forma contractual y particularmente por la representación que naturalmente va envuelta en ella (...se hace cargo de ellos por cuenta y riesgo de...) cabría mejor una calificación del contrato como prestación de servicios profesionales ${ }^{54}$.

El objeto materia de la prestación del servicio, en este caso, se aleja de la tipificación como simple obligación de diligencia o de medios. En efecto, el objeto del encargo consistente en redactar uno o más actos jurídicos determinados donde el cliente sea autor o parte, se revelaría más cercano a un resultado concreto que se espera del profesional, que a una promesa de hacer todo lo posible para alcanzar dicho resultado. Este encargo, como resultado material, que se traduce en la escrituración material de un acto jurídico, además de reflejar estrictamente las instrucciones del cliente, debe contener los elementos esenciales (sean generales o de existencia y validez, sean especiales o propios al acto en cuestión) y todos los elementos accidentales queridos por su autor, para que pueda producir todos sus efectos jurídicos. No contiene, a priori, determinadamente el alea o incertidumbre que caracteriza a la gestión judicial-contenciosa del abogado cuando asume la defensa del cliente en juicio.

En este encargo, habría una suerte de doble deber que se impone al abogado según los términos de la Corte de Casación francesa: por una lado, un deber de eficacia que exige al profesional ser efectivo en la elaboración de documentos fiables, asegurando su validez y plena eficacia; y por el otro, una suerte de deber de curiosidad, que exige "una actitud activa del abogado que deberá obtener de su propia iniciativa el conjunto de documentos y elementos propios para permitirle asegurar mejor la protección de intereses del cliente" ${ }^{\prime 5}$. Ese mismo tribunal llega a imponer al abogado la obligación de "aclarar a su cliente sobre sus derechos

\footnotetext{
${ }^{53}$ Art. 413 СОT. "Las escrituras de constitución, modificación, resciliación o liquidación de sociedades, de liquidación de sociedades conyugales, de partición de bienes, escrituras constitutivas de personalidad jurídica, de asociaciones de canalistas, cooperativas, contratos de transacciones y contratos de emisión de bonos de sociedades anónimas, solo podrán ser extendidas en los protocolos notariales sobre la base de minutas firmadas por algún abogado.

Asimismo, el notario dejará constancia en las escrituras del nombre del abogado redactor de la minuta. La omisión de esta exigencia no afectará la validez de la escritura.

Las obligaciones establecidas en los incisos anteriores no regirán en los lugares donde no hubiere abogados en un número superior a tres.

El notario autorizará las escrituras una vez que estas estén completas y hayan sido firmadas por todos los comparecientes".

${ }^{54}$ BRANTT y MEJÍAS (2016), pp. 71-103; BARROS (2012), pp. 326-329; RODRÍGUEZ (2008), pp. 503-517 y SEVERÍN (2015), pp. 357389.

${ }^{55}$ Cass. Civ. 1a 1 de marzo de 2005, Pourvoi Nº3-16.329.
} 
informándole de las consecuencias jurídicas de la operación que se le encomienda y de disuadirlo de ella si ésta amenaza de ser perjudicial para él" ${ }^{56}$, estableciendo, además, que si los elementos de que dispone son insuficientes para llevar a cabo el encargo, debe expresar las reservas necesarias y efectuar la búsqueda de esos antecedentes indispensables ${ }^{57}$. Aunque la Corte de Casación francesa no llega al punto de calificar expresamente, como sí lo hace cierta doctrina ${ }^{58}$, este encargo como una obligación de resultado; su solución, empero, es muy próxima a esa calificación, en la medida que exige la sola constatación de que el acto encomendado no resultó eficaz para establecer la responsabilidad civil del abogado, quien debe responder por los daños sufridos por el cliente, bastándole a este la sola prueba del perjuicio ${ }^{59}$.

La obligación de información del abogado redactor, en claro, se adapta mejor a la categoría de obligaciones de medios o de resultado.

En efecto, la obligación de información del abogado se revela con una dimensión diferente en esta materia con relación a la que pudimos analizar cuando el abogado recibe el encargo de defender derechos del cliente en juicio. Esta dimensión distinta proviene de las exigencias particulares que vienen dadas por el imperativo de garantizar la validez y eficacia del acto o contrato cuya redacción se le encarga, es decir, por el resultado concreto que legítimamente espera el cliente de su abogado.

Como ya pudimos adelantar en otro trabajo, la obligación de información del abogado redactor aparece aquí en un estadio superior a la simple obligación de transmitir información jurídica al cliente y todavía menos solo al término del encargo, pues le impone una obligación de consejo ${ }^{60} \mathrm{o}$ incluso de desaconsejar la conclusión del acto o contrato que se le encarga ${ }^{61}$, lo que implica informar constantemente antes de la conclusión de este.

De ahí que se revele que el abogado asume un rol activo en esta materia, estando impedido de excusarse de alegar que no fue requerido por el cliente para hacer frente a una determinada consecuencia que se produciría para este por la suscripción o celebración del acto jurídico cuya redacción se le ha encomendado. Además, le está vedado excusarse en el hecho que el cliente no le hizo entrega de todos los antecedentes, documentos o información para cumplir a cabalidad con el encargo. Incluso más, su deber de simple información e incluso de consejo puede extenderse a terceros, en particular al co-contratante de su cliente.

\footnotetext{
${ }^{56}$ Cass. Civ. 1a, 10 de junio de 1997, Pourvoi N95-17.213, relativo a un asunto en donde el cliente contrata los servicios del abogado para la redacción de un proyecto de cesión de partes sociales en una sociedad determinada a otra sociedad que las adquiriría. Las instrucciones eran que consignara una condición suspensiva relativa a la liberación previa de su calidad de garante de las obligaciones de la sociedad. La cesión se firma sin ninguna prevención y producida la liquidación judicial de la sociedad la cedente es condenada en tanto caución al pago de una suma de dinero al acreedor. La Corte de Casación confirma lo resuelto por la Corte de Apelaciones que considera que "el abogado incurre en culpa profesional por no haber disuadido a su cliente, comercianteartesano sin formación jurídica, de firmar la cesión sin haber previamente obtenido el acuerdo previo del cesionario de sustituirse al cedente como garante." En el mismo sentido CA Versailles, 1a sala, sección 1, 15 de mayo de 2014, RG № 11/07634.

${ }^{57}$ Cass. Civ. 1ạ, 21 de mayo de 1996, Pourvoi $N^{\circ}$ 94-12.974, condenando a un abogado suizo que redacta mal un testamento, confiriéndole derechos a un medio hermano del cliente-causante en circunstancias que, conforme a las reglas sucesorales francesas, quedaba excluido existiendo herederos con mejor derecho de suceder. Para un caso en que la Corte impone el deber de informar sobre las consecuencias financieras de la ruptura de un contrato de trabajo, a un abogado a quien se le encarga redactar la carta de despido de un trabajador de su cliente: Cass. Civ. 1á, 13 de marzo de 1996, Bulletin $\mathrm{N}^{\circ} 132$. Cour d'appel de Paris, du 20 septembre 1993.

${ }^{58}$ ADER y DAMIEN (2012), p. 41

${ }^{59}$ Cass. Civ. 1a 7 de diciembre de 2004, Pourvoi $\mathrm{N}^{\circ}$ 02-15.578, condenando a un abogado que no investigó en el contrato de seguro de la nave comprada por su cliente si éste aseguraba los graves desperfectos que presentaba. En el juicio por responsabilidad civil la aseguradora es liberada, condenando a la vendedora al pago de una indemnización. La demandada cae luego en liquidación judicial, sin que el comprador pueda obtener el pago de su acreencia.

${ }^{60}$ Sobre las diferencias entre la simple obligación de informar y la obligación de aconsejar, remitimos a nuestro trabajo anterior (BOZZO y RUZ, "El deber precontractual de información del abogado"), en donde expresamos que "el deber de consejo, sería un deber calificado de informar que supone, entonces, más allá de la simple transmisión de una información jurídica bruta comprensible para el cliente, una operación consistente en aplicar esta información a la situación jurídica que le presenta el cliente, posicionando la norma a ese u otros escenarios fácticos previsibles, emitiendo una opinión o recomendación acerca de la mejor forma cómo debiera conducirse el cliente en cada caso para proteger sus intereses". GAVARD-GUILLES (1995), p. 501, lo resume así: "dar un consejo no es solamente entregar información bruta, sino aclarar sobre el contenido de esa información y mostrar las deducciones o conclusiones que se pueden extraer de ella. (...) la obligación de consejo necesita de recomendaciones positivas más precisas y detalladas".

61 JULIEN (2005), pp. 11-15.
} 
En efecto, la Corte de Casación francesa ha considerado, en ocasiones, retener la responsabilidad extracontractual del abogado que no ha informado eficientemente al tercero contratante. Se ha fallado, por ejemplo, que "los redactores del acto o contrato asumen una obligación de consejo respecto de todas las partes en presencia y deben asegurar la validez y eficacia de los actos que confeccionan"62; "que el redactor del acto asume la obligación de informar y de aclarar de manera completa a todas las partes, particularmente sobre las incidencias tributarias, sin poder descargarse de esta obligación por las competencias personales de una de las partes o por la presencia a su lado de un consejero personal" 63; "el redactor debe velar por asegurar el equilibrio del conjunto de intereses en presencia y de tomar la iniciativa de aconsejar a las partes de la convención sobre el alcance de las obligaciones de una $u$ otra, sin importar que el acto haya sido firmado en su ausencia y redactado por requerimiento de uno solo de los contratantes" 64 , debiendo el abogado redactor "aportar la prueba de que ha cumplido con esta obligación, cualquieras sean las competencias personales de los contratantes" 65 .

Como se puede apreciar de estas decisiones, respecto de las cuales no vemos inconveniente de aplicar en nuestro país una doctrina similar, puede concluirse que el abogado que asume la misión de redactar un acto o contrato, se obliga a un resultado determinado donde la obligación de informar adquiere esta misma naturaleza. De no poder alcanzar este resultado por falta de antecedentes el abogado debe abstenerse de prestar sus servicios, hasta no desplegar todas las acciones tendientes a obtener dichos antecedentes, imponiéndosele al profesional, además, la tarea de informar calificadamente acerca de todas las consecuencias que la realización del encargo tendrá para su cliente, debiendo incluso desaconsejar la realización de este.

\subsection{El suministro de información y deber de consejo como objeto principal del encargo}

La asesoría jurídica, como expresión de una dedicación profesional de los abogados en el ejercicio de su trabajo, no es demostrativa de ninguna especialización. Sin embargo, proponemos para los efectos de esta contribución, entenderla como un área de ejercicio que se antepone al litigio, intentando precaverlo o evitarlo. El objeto principal de la prestación de servicios del abogado asesor-jurídico es precisamente entregar al cliente, de forma permanente o en casos puntuales, la información necesaria que este le requiera y, en su caso, aconsejarle en base a ella, la decisión que más convenga a sus intereses.

De ahí que se perciban dos fases distintas en la labor de asesoría jurídica. La primera, en donde el objeto de la asesoría constituye la simple transmisión de información, y la segunda, que se posiciona en un grado más calificado de entrega de información, que es el consejo.

\subsubsection{La transmisión de información como objeto principal del contrato cliente-abogado}

Lo primero que conviene dejar establecido, como ya se ha avanzado, es que en la función de asesoría jurídica la información que transmite al abogado al cliente constituye el objeto principal de su obligación y no una prestación accesoria. Sin embargo, la asesoría jurídica puede presentarse bajo distintas fórmulas o grados, en donde la intensidad de la obligación de información será determinante para posicionarse en unas u otras.

\footnotetext{
62 Cass. Civ., 1a, 14 de enero de 1997, Pourvoi №94-16.769, sancionando a un abogado que al redactar un préstamo de una gran suma de dineroque no consigna ninguna garantía de reembolso, estableciendo la culpa del redactor del acto por violar su deber de información y su obligación de consejo.

${ }^{63}$ Cass. Civ., 1a 9 de noviembre de 2004, Pourvoi $\mathrm{N}^{\circ}$ 02-12.415, sancionando al abogado que además es d'expert-comptable por no informar las consecuencias fiscales de la cesión que él redactó.

${ }^{64}$ Cass. Civ., 1a , 27 de noviembre de 2008, Pourvoi $\mathrm{N}^{\circ}$ 07-18.142, sancionando a un abogado redactor no de un simple modelo, sino de un proyecto finalizado enteramente redactado por él bajo su cuidado.

${ }^{65}$ Cass. Civ., 1aㅡ, de febrero de 2010, Pourvoi N09-11.591, condenando a un abogado por no haber informado las consecuencias tributarias de la cesión de un fondo de comercio que redacta para su cliente quien había heredado 5 años antes ese establecimiento.
} 
En esta primera hipótesis de asesoramiento jurídico el cliente contrata los servicios profesionales del abogado con el único fin de requerirle que le entregue información sobre una determinada materia y este cumple la prestación entregando, sea verbalmente, sea mediante un informe escrito, la información solicitada. No hay, entonces, prevenciones, deducciones, conclusiones o recomendación alguna que emane del profesional. El objeto material, el aspecto formal de la prestación es medible por un resultado concreto: la entrega de la información requerida. Piénsese en las asesorías que contratan los congresistas para poder luego fundar un proyecto de ley o configurar fundadamente una idea de legislar sobre una determinada materia; o en la solicitud que hace una parte a un abogado especialista para que evacúe un informe en derecho.

Se trata, en concreto, de una asesoría que se contrata para informarse sobre el marco legal, doctrinal o jurisprudencial aplicable a una situación determinada. Sobre esa base el cliente es quien tomará una decisión que le reporte algún beneficio o le evite un perjuicio. La entrega efectiva de la información en la forma y oportunidad requerida por el cliente será medible por un resultado concreto, no así el contenido claro, veraz, exacto, actualizado y pertinente de la información. De ahí que no sea exigible que el informe entregado por el abogado abrace una información compartida por todos, lo que se espera es que el informe contenga, más allá de la opinión del letrado, suficiente información que le permita al cliente tomar una decisión, con conocimiento de causa. Consecuencia de ello es que en relación al contenido de la información se mida esta obligación como una de medios ${ }^{66}$.

En esta hipótesis de análisis, no es exigible, en principio, la observancia por el abogado de un deber de mise en garde o de prevención o de advertencia frente a un riesgo que pudiera presentarse para el cliente. Sin embargo, si las condiciones especiales en que se desarrolla el encargo permiten concluir que la información entregada, para ser mejor comprendida, debía contener "un llamado de atención" al cliente para que tomare las precauciones necesarias o adoptare un comportamiento adecuado a fin de posicionarlo mejor frente al riesgo, podría resultar exigible, sin que ello signifique desnaturalizar la prestación original de una simple de información hacia un consejo.

\subsubsection{El consejo o la recomendación como objeto principal del contrato cliente-abogado}

Hemos avanzado que el consejo es mucho más que la simple transmisión de información. "Dar un consejo no es solamente entregar información bruta, sino aclarar sobre el contenido de esa información y mostrar las deducciones o conclusiones que se pueden extraer de ella. (...) la obligación de consejo necesita de recomendaciones positivas más precisas y detalladas" 67. Todavía más claro lo expresa la profesora Fabre-Magnan: "el consejo corresponde entonces a la puesta en relación de la información bruta con el objetivo perseguido por el acreedor de la información"68. En realidad, siguiendo a esta misma doctrina, "la obligación de consejo se distingue de la obligación de informar únicamente por el contenido, el grado de información transmitida" 69 .

\footnotetext{
${ }^{66}$ En este sentido SERRA (2001), pp. 271 y 272 al indicar: "El abogado que asume el encargo de elaborar un dictamen o emitir un informe jurídico se obliga a alcanzar un resultado que consiste precisamente en tener preparado en el tiempo pactado un dictamen o un informe que reúnan unas mínimas condiciones cualitativas de exactitud e idoneidad. En este supuesto particular, la prestación fundamental del abogado es el resultado "emisión de un informe o redacción de un dictamen"; no, en cambio la pura actividad de revisión y examen jurídico de la cuestión planteada". En este mismo sentido se pronuncia en España CRESPO (2005), p. 154, al sostener que el abogado cumple con la entrega del informe solicitado y no con asegurar la consecución de un ulterior resultado. En España la doctrina es unánime al considerar que a la hipótesis en estudio le son aplicables las reglas del arrendamiento de obra, lo que supone calificar el informe cuyo objeto principal es la información como una obligación de resultado, ya que no se compromete una mera actividad, sino el resultado de la misma, en este caso el informe en derecho o dictamen. Así se pronuncian entre otros, PUIG (1956), p. 350; LUCAS (1986), p. 36; CABANILLAS (1993), p. 70; YZQUIERDO (1998), p. 59; y SERRA (1998), p. 303.

67 GAVARD-GUILLES (1995), p. 501

68 FABRE-MAGNAN (1992), p. 385.

${ }^{69}$ FABRE-MAGNAN (1992), p. 385. En España, PÉREZ (1990), p. 314, señala que, si bien existe una línea divisoria entre la información y el consejo, reconoce que no se trata de conceptos antagónicos. KRALIK (1978), pp. 11 y 12, admite, en relación con la obligación de informar de los notarios, las dificultades para distinguir el deber de información del deber de consejo.
} 
En el consejo, el objeto principal de la prestación que se obliga a dar o hacer el abogado se edifica a partir de la información que el cliente ha procurado previamente al abogado y del análisis que este ha hecho de dicha información, pero se cumple o ejecuta con una recomendación donde el cliente espera que su abogado le entregue una apreciación juiciosa y fundada que le allane el camino de la decisión que debe adoptar respecto de un determinado asunto, conflicto o problema. Como señala Crespo Mora: "El consejo comienza siendo inicialmente información o mera transmisión de datos o hechos objetivos. Pero, luego, el consejo va más allá. El consejo, asesoramiento o recomendación implican dar a conocer a otra persona lo que considera más ventajoso en su situación y que el mismo haría si estuviese en su lugar. Por tanto, el consejo va ligado a un juicio de valor sobre un acto futuro del aconsejado y a una invitación o exhortación para que el destinatario del consejo actúe de una determinada manera"70.

Recomendación y consejo no son términos que nuestro legislador desconozca ${ }^{71}$. Sin embargo, han sido tomados en un contexto distinto, en sede de contrato de mandato, cuya calificación no se aviene, como hemos dicho, con la relación contractual cliente-abogado y particularmente en el contexto de una asesoría jurídica. En efecto, de las fuentes empleadas por Andrés Bello en la redacción del artículo 2119 del Código civil 72 , Troplong es quien más claramente muestra el contexto diferente al que se refiere la recomendación y el consejo en la disciplina del mandato en el Código civil. Recuérdese que el mandato en sede del Code civil era un contrato gratuito, altruista, basado en la confianza que la amistad entregaba. Esta fuente se cuestionaba: "Entre el mandato y el consejo, hay una enorme diferencia: ¿si yo hago libremente lo que mi amigo lealmente me ha aconsejado, de qué podría yo quejarme en caso de no tener éxito?, ¿es acaso una orden que él me ha dado?, ¿no era acaso yo dueño de seguir su opinión? Sin duda, si el consejo ha sido fraudulento, yo tendré acción en su contra. Pero, incluso en ese caso, la acción no sería la acción mandati, sino la acción dolo"73. En claro, el consejo y la recomendación en sede de mandato demuestran precisamente la ausencia de este contrato y de todo contrato en general entre quien lo da y quien lo recibe. Nuestra hipótesis de estudio, por lo tanto, es diametralmente distinta, pues en el consejo como objeto del asesoramiento jurídico hay, ante todo, contrato, y el objeto de este es, precisamente, el consejo o recomendación que se pide (onerosamente) por un cliente a su abogado.

En concreto, la diferencia entre el deber de información y el de consejo, radica que -en el primer supuesto- el profesional entrega información objetiva, de carácter neutra, sin advertir ni recomendar al cliente respecto de la decisión que debe adoptar; en cambio, en el segundo, en el asesoramiento, el cliente espera, pues ese es el objeto del consejo, que el letrado le proponga dentro de una variedad de soluciones aquella que mejor parece proteger los intereses del cliente. El abogado no decide por el cliente, lo orienta, lo ayuda a evaluar las posibilidades de éxito o fracaso, le advierte los riesgos asociados. El cliente es siempre dueño de la decisión definitiva. De ahí que, la información que entrega el abogado al cliente a quien aconseja no pueda medirse por un resultado concreto, en términos de saber si el consejo fue el mejor, sino como una obligación de medios. Lo que si puede medirse por un resultado determinado o concreto es el consejo mismo, es decir, la transmisión efectiva de la recomendación solicitada. Si el cliente alega no haber recibido sino información bruta, habiendo contratado un consejo del abogado, este solo podrá excusarse de la no entrega del consejo probando caso fortuito o fuerza mayor. Si, además, entre la ausencia del consejo y el daño que se produce para el cliente se comprueba el debido nexo causal, podría verse comprometida la responsabilidad civil del abogado. En cambio, la comprobación causal de un consejo errado y el daño ocasionado al

\footnotetext{
${ }^{70}$ CRESPO (2005), p.184.

${ }^{71}$ Art. 2119 CC. "El negocio que interesa al mandatario solo, es un mero consejo, que no produce obligación alguna.

Pero si este consejo se da maliciosamente, obliga a la indemnización de perjuicios".

72 Del Código de las Siete Partidas (L. 23, tít. 12, P. 5a); de POTHIER (mandat, n¹5 y ss.) y TROPLONG (§15).

73 TROPLONG (1846), p. 25
} 
cliente exigirá la constatación de una falta de prudencia o diligencia del abogado para hacerlo responsable.

\section{Conclusiones}

1. Del análisis de la obligación de información del abogado para con su cliente, en las dos grandes áreas en que se ha dividido este trabajo, sea cuando aquel asume la defensa de los derechos de este en juicio o cuando el encargo consista en redactar determinados actos o contratos o dar asesoría jurídica o prestar consejo, el contenido, oportunidad y extensión de la obligación de información, se vuelve compleja y, en todo caso, se extiende más allá de la simple obligación de rendir cuenta al término del encargo, como lo previene expresamente el Código Civil en las reglas del contrato de mandato.

2. Se concluye que, tratándose del encargo de asumir la defensa judicial del cliente, el reenvío que se hace al mandato para calificar el contrato que vincula a este con su abogado revela evidentes insuficiencias, lo que exige recurrir a fuentes deontológicas propias de la profesión y a la noción de obligaciones implícitas que ha sido desarrollada por la doctrina y jurisprudencia para llenar los vacíos de regulación. Si bien, es cierto que el reconocimiento y la aplicación de esta noción doctrinaria facilita el estudio del contenido y extensión de la obligación de información, no es menos cierto que, al mismo tiempo, también dificulta su tipificación abstracta como obligación de medios o de resultados, lo que no impide concluir que, aun cuando el objeto del encargo, la defensa judicial del cliente en los asuntos contenciosos que se le encargan, mantiene su calificación como obligación de medios o de diligencia, la correcta ejecución de la misma exige el cumplimiento de obligaciones intermedias que sí se miden por su resultado y que comunican este carácter a la obligación de información del abogado.

3. En el orden de los encargos no judiciales es distinta la situación, ya que tanto el objeto del encargo como la obligación de información que pesa sobre el abogado se configuran preferentemente como obligaciones de resultado. Así, por un lado, cuando el encargo que se hace al abogado es el de redactar un acto o contrato, se concluye que el letrado al comprometer un resultado determinado comunica esta naturaleza a la obligación de informar, la que se extiende, entre otros aspectos, al imperativo de informar calificadamente acerca de todas las consecuencias que la realización del encargo tendrá para el cliente, debiendo incluso desaconsejar la realización del objeto del encargo si este se revelase contrario a sus intereses. Por otro lado, en el área en donde la obligación de información se erige como objeto principal del encargo para el que se contrata al abogado, es decir, cuando este consiste en dar asesoría jurídica, sea suministrando información jurídica simple al cliente o compleja dándole consejo o recomendaciones, solo la transmisión de esta información se mide por un resultado concreto, pues el contenido, exactitud, veracidad y pertinencia de la misma constituye una obligación de medios que exigirá del cliente la constatación de una falta de prudencia o diligencia del abogado para comprometer su responsabilidad civil.

\section{BIBLIOGRAFÍA CITADA}

Ader, HenRi y Damien, Andre (2012): Règles de la profession d'avocat (París, Dalloz action).

APPLETON, JeAn (1928): Traité de la profession d'avocat (Paris, Dalloz).

BARCIA LAGO, Modesto (2008): "El surgimiento de la profesión de abogado en Roma", en: Barcia Lago, Modesto, Abogacía y ciudadanía. Biografía de la abogacía ibérica (Madrid, Dykinson), pp. 183-266.

BARROS BOURIE, ENRIQUE (2012): "Los contratos de servicios ante la doctrina general del contrato: la virtualidad analógica de las reglas del mandato", en: Elorriaga de Bonis, Fabián (Ed.), Estudios de Derecho Civil VII (Santiago, Abeledo Perrot), pp. 326-329. 
Brantt Zumarán, María Graciela y Mejías Alonzo, Claudia (2016): "El derecho supletorio del contrato de servicios en el código civil chileno. Insuficiencia de las reglas del mandato y del arrendamiento", en: Revista de Derecho de la Pontificia Universidad Católica de Valparaíso (Vol. XLVI), pp. 71-103.

CABANILlAS SÁNChEZ, ANTONIO (1993): Las obligaciones de actividad y de resultado (Barcelona, Bosch).

CASEAU-Roche, Cecile y Wittmann, Valerie (2014): “Responsabilité civile de l'avocat et procédure: tendances jurisprudentielles", en: Dalloz avocats - Exercer et entreprendre, pp. 312 y ss.

DE ÁNGEL YAGÜEZ, RICARDO (2000): "Responsabilidad por informar", en: Moreno Martínez, Juan Antonio (Coord.), Perfiles de la responsabilidad civil en el nuevo milenio (Madrid, Dykinson), pp. 169-203.

CRESPO MORA, MARÍA CARMEN (2005): La responsabilidad del abogado en el derecho civil (Navarra, Civitas).

DE LA MAZA (2002): Los abogados en Chile: Desde el Estado al Mercado, en: Colección Informes de Investigación (№ 10, Año 4, enero de 2002), pp. 193-216.

Delvincourt, Claude-Etienne (1819): Cours de code civil (Paris, Imprimerie de Lebégue), tomo III.

Demogue, Rene (1925): Traité des obligations en général (Paris, A. Rousseau), tomo 5.

DougnaC RodríGuez, ANTONIO (1994): Manual de Derecho Indiano (México, Universidad Autónoma de México).

FESSARD, BRUNELLE (2015): "Les obligations non matérialisées dans les contrats, Thèse doctorat Université Montpellier". Disponible en https://tel.archives-ouvertes.fr/tel-01342592 [visitado el 28 de diciembre de 2017].

Fueyo LANERI, FernANDo (2010): "Algunos aspectos del negocio fiduciario", en: Tavolari Oliveros, Raúl (Dir.), Doctrinas esenciales. Derecho civil. Contratos (Santiago, Editorial Jurídica de Chile), tomo II, pp. 865-884.

GabBa, CARlo Francesco (1912): Nuove Questioni di Diritto Civile (Torino, Fratelli Bocca Editori), tomo I.

GARDNER, DANIEL Y MOORE, BENOIT (2007): "La responsabilité contractuelle dans la tourmente", en: Les Cahiers de droit (Vol. 48, № 4), pp. 543-578.

GAVARD-GILleS, ANNe-MARIE (1995): “Celui qui accepte de donner des renseignements a lui-même l'obligation de s'informer pour informer en connaissance de cause", en: Recueil Dalloz, pp. 499 y ss.

Gertosio Páez, Alberto (2005): "Los abogados en el Chile indiano a la luz de las 'relaciones de méritos y servicios'”, en: Revista de Estudios Histórico-Jurídicos (XXVII), pp. 233-250.

GILSON-MAES, ANNE (2016): Mandat et responsabilité civile (Paris, LGDJ).

JOSSERAND, LOUIS (1934): “L'essor moderne du concept contractuel”, en : VV.AA., Recueil d'études sur les sources du droit en l'honneur de François Gény (Paris, Sirey), tomo II, pp. 333-346.

(1937): "Aperçu général des tendances actuelles de la théorie des contrats", en : RTD. civ., pp. 1 y ss.

JULIEN, JEROME (2005): “De l'obligation de (dé) conseil de l'avocat", en: Revue Lamy Droit civil (№ 17), pp. 11-15. 
KRAliK, Winfried (1978): "El deber de informar del Notario", en: Anales de la Academia Matritense y del Notariado (núm. 22-II), pp. 9-30.

LOYOLA LOYOLA, RICARDO (2013): “El abogado: Breve reseña de su evolución y características", en: Revista de Filosofía y Ciencias Jurídicas (Año 2, № 2, julio de 2013), pp. 134-148.

LUCAS FERNÁNDEZ, FERNANDO (1986): “Comentario a los artículos 1583 a 1587 Cc", en: Albaladejo, Manuel (Coord.), Comentarios al Código civil y Compilaciones forales (Madrid, Edersa), tomo XX, vol. 2, pp. 44-75.

MARTínez VAL, JOSÉ MARía (1993): Abogacía y abogados. Tipología profesional, lógica y oratoria forense, deontología jurídica (Barcelona, Bosch).

PÉREZ GARCíA, PEDRO ANTONIO (1990): La información en la contratación privada. En torno al deber de informar en la Ley General para la Defensa de los Consumidores y Usuarios (Madrid, Instituto Nacional de Consumo).

Peñailillo Arévalo, Daniel (2003): Obligaciones. Teoría general y clasificaciones. La resolución por incumplimiento (Santiago, Editorial Jurídica de Chile).

PIZARRO WILSON, CARLOS (2008): "La culpa como elemento constitutivo del incumplimiento en las obligaciones de medio o de diligencia", en: Revista de Derecho de la pontificia Universidad Católica de Valparaíso (XXXI), pp. 255-265.

PUig BRUtAU, José (1956): Fundamentos de derecho civil (Barcelona, Bosch), tomo II, vol. II.

ROdRíGUez PINTO, MARÍA SARA (2008): "Incumplimiento y exoneración de responsabilidad en los contratos de servicios", en: Guzmán Brito, Alejandro (Ed.), Estudios de derecho civil III (Santiago, LegalPublishing), pp. 503-517.

SAINCTELETTE, ChARLES (1884): De la responsabilité et de la garantie (Bruxelles-Paris, BruylantMarescq).

SALEILles, RaIMOND (1901): De la déclaration de volonté (Paris, Pichon).

SeVERín Fuster, GonzAlo (2015): "Sobre el modelo de contratación de servicios remunerados en el derecho romano. Algunos aspectos relevantes de la locatio conductio", en: Revista de Derecho de la Universidad Católica del Norte (Año 22, № 2), pp. 357-389.

SerRa Rodriguez, Adela (1998): "Responsabilidad civil del abogado. Comentario de la STS de 28 de enero de 1998 (RJ 1998, 357)”, en: Revista de Derecho Patrimonial (№ 1), pp. 301-308.

(2001): La responsabilidad Civil del Abogado (Navarra, Aranzadi).

TROPLONG, RAYMOND-THEODORE (1846): Le droit civil expliqué suivant l'ordre des articles du Code, depuis et y compris le titre de la vente. Du mandat. Commentaire du titre XIII du livre III du Code civil (Paris, C. Hingray), tomo 16.

VERCHERE, VALENTIN (1840): La Vérité sur la profession d'avocat (Paris, Delamotte).

YZQUieRdo Tolsada, MARIANo (1998): "Responsabilidad civil del abogado", en: Fundación Central Hispano (Ed.), La Universidad y las profesiones jurídicas (Deontología, Función social y Responsabilidad) (Consejo de la UCM, Madrid), pp. 43-95. 


\section{JURISPRUDENCIA CITADA}

SENTENCIA CS (1906): Corte Suprema 22 junio 1906 en: Gaceta 1906, Tomo I, № 388, p. 643. SENTENCIA CS (1920): Corte Suprema 5 julio 1920 en: Repertorio, Tomo 19, sección 1ạ , p. 145. CORTE DE CASACIÓN, SALA COMERCIAL, 3 de noviembre de 1992, Bull civ| IV, n 338; RTD. Civ. 1993, p. 124, obs. J. Mestre; JCP 1993, II, 22164, obs. G. Virassamy.

CoRTE de CASACIÓN, PRIMERA SALA CIVIL, 13 de marzo de 1996, Pourvoi № 93-20578, casando una decisión de la Corte de Apelaciones de Paris, de 20 de septiembre de 1993. Disponible en: https://www.legifrance.gouv.fr/affichJuriJudi.do?oldAction=rechJuriJudi\&idTexte=JURITEXT00 0007035555\&fastReqld=1461214677\&fastPos=12 [visitado el 28 de enero de 2018].

CORTE de CASACIÓN, PRIMERA SALA CIVIL, 21 de mayo de 1996, Pourvoi Nº 94-12.974. https://www.legifrance.gouv.fr/affichJuriJudi.do?oldAction=rechJuriJudi\&idTexte=JURITEXT00 0007297347\&fastReqld=250633390\&fastPos=1 [visitado el 28 de enero de 2018].

CORTE DE CASACIÓN, PRIMERA SALA CIVIL, 14 de enero de 1997, Pourvoi N94-16.769 casando la decisión de la Corte de Apelaciones d'Orléans de 6 de abril de 1994. Disponible en: https://www.legifrance.gouv.fr/affichJuriJudi.do?idTexte=JURITEXT000007037192 [visitado el 28 de enero de 2018].

CORTE DE CASACIÓN, PRIMERA SALA CIVIL, 10 de junio de 1997, Pourvoi N95-17.213, confirmando una decisión de la Corte de apelaciones de Paris (1a sala, sección A), de 13 de febrero de 1995. Disponible en: https://legimobile.fr/fr/jp/j/c/civ/1ere/1997/6/10/95-17213/ [visitado el 18 de enero de 2018].

Corte de Apelaciones de Québec, Provigo Distribution inc. C. Supermarché A.R.G. INC., [1998] R.J.Q. 47.

CORTE DE CASACIÓN, PRIMERA SALA CIVIL, 7 de octubre 1998, Bull. civ. I, nº 282.

CORTE DE CASACIÓN, TERCERA SALA CIVIL, 15 de noviembre de 2000, D. 2002, somm. 928, note 0. Tournafond; JCP 2002, II, 10054, note Ch. Lièvremont.

CORTE DE CASACIÓN, PRIMERA SALA CIVIL, 16 mars 2004, D. 2004 n² 25 p. 1754, D. Mazeaud; RLDC, $n^{\circ}$ 6, juin 2004, p. 5, D. Houtcieff; JCP E 2004, p. 737, Renard-Payen.

CASS. CIV., 1a 9 de NOVIEMBRE DE 2004, PouRVoI Nº2-12.415, CASANDO UNA SENTENCIA DE LA CORTE DE APELACIONES DE PARÍS DE 7 diciembre de 2001. Disponible en: https://www.legifrance.gouv.fr/affichJuriJudi.do?oldAction=rechJuriJudi\&idTexte=JURITEXT00 0007049620\&fastReqld=1476109575\&fastPos $=1$ [visitado el 28 de enero de 2018].

CORTE DE CASACIÓN, PRIMERA SALA CIVIL, 7 de diciembre de 2004, Pourvoi № 02-15.578, confirmando una decisión de la Corte de apelaciones de Versailles (1aㅡ sala, 1a sección), de 4 de abril de 2002. Disponible en: https://www.legifrance.gouv.fr/affichJuriJudi.do?oldAction=rechJuriJudi\&idTexte=JURITEXT00 0007471583\&fastReqld=1162520559\&fastPos=1 [visitado el 28 de enero de 2018].

CORTE DE CASACIÓN, PRIMERA SALA CIVIL, 1 de marzo de 2005, Pourvoi № 03-16.329, casando una decisión de la Corte de Apelaciones d'Agen, de 12 de septiembre de 2001. Disponible en: https://www.legifrance.gouv.fr/affichJuriJudi.do?oldAction=rechJuriJudi\&idTexte=JURITEXT00 0007050668\&fastReqld $=185166004 \&$ fastPos $=1$ [visitado el 15 de enero de 2018].

TRIBUNAL SUPREMO ESPAÑOL, 18 de febrero de 2005, RJ 2005, p.1682.

TRIBUNAL SUPREMO ESPAÑOL, 14 diciembre 2005, RJ 2006, p. 1225. 
CASS. CIV., 1ą 27 dE NOVIEMBRE DE 2008, POURVOI Nº7-18.142, CONFIRMANDO LA DECISIÓN DE LA CORTE DE APELACIONES D'ANGERS, DE 6 de junio de 2007. Disponible en: https://www.legifrance.gouv.fr/affichJuriJudi.do?oldAction=rechJuriJudi\&idTexte=JURITEXT00 0019842220\&fastReqld=1608851555\&fastPos=1 [visitado el 28 de enero de 2018].

CORTE de CASACIÓN, PRIMERA SALA CIVIL, 14 de mayo de 2009, Bull. civ. I, n 92; D. 2010, Pan. 49, obs. Brun; RTD civ. 2009. 493, obs. Deumier.

CASS. CIV., 1ạ, de feBreRo de 2010, Pourvol N09-11591, CASANDO LA DECISIÓN DE LA CORTE DE APELACIONES DE BORDEAUX, DE 1 de diciembre de 2008. Disponible en: https://www.legifrance.gouv.fr/affichJuriJudi.do?oldAction=rechJuriJudi\&idTexte=JURITEXT00 0021884899\&fastReqld=1601605390\&fastPos=1 [visitado el 28 de enero de 2018].

CORTE DE CASACIÓN, PRIMERA SALA CIVIL, 16 de enero de 2013, pourvoi № 12-14.439, D. 2013. 619, obs. I. Gallmeister, note M. Bacache; RTD civ. 2013. 380, obs. P. Jourdain.

ASENSIO CON CASTILLO (2013): CORTE SUPREMA 28 enero 2013 (casación en el fondo-Indemnización de perjuicios) en: Westlaw Chile (cita online: CL/JUR/174/2013) [visitado el: 23 de noviembre de 2020].

CORTE DE CASACIÓN, SALA COMERCIAL, 29 de enero de 2013, Pourvoi № 11-23676, casando una decisión de la Corte de apelaciones de Montpellier, de 17 de mayo de 2011. https://juricaf.org/arret/FRANCE-COURDECASSATION-20130129-1123676 [visitado el 28 de enero de 2018].

CORTE de APELACIONES DE VerSAilles, 1a SALA, SECCIÓN 1, 15 de mayo de 2014, RG № 11/07634. Disponible en http://www.jurisprudentes.net/La-responsabilite-de-l-avocat-8575.html [visitado el 28 de enero de 2018].

PÁEZ CON ROJAS (2014): Corte de Apelaciones de Antofagasta 23 septiembre 2014 (recurso de apelación, incumplimiento de contrato e indemnización e perjuicios), en: Microjuris (cita online: MJCH_MJJ39132) [visitado el 23 de noviembre de 2020].

Corte de Apelaciones de QuéBeC, Dunkin's Brands Canada LTd. C. Bertico inc., 2015 QCCA 624.

SÁEZ CON CLUB DE ÑUble (2015): Corte de Apelaciones de Chillán 6 abril 2015 (recurso de nulidad laboral)

en: https://corte.pjud.cl/SITCORTEPORTAL/DownloadFile.do?TIP_Documento=3\&TIP_Archivo=1\& COD_Opcion=1\&COD_Corte=45\&CRR_IdTramite=12349407\&CRR_IdDocumento=10869947 [visitado el 23 de noviembre de 2020].

CORTE DE CASACIÓN, PRIMERA SALA CIVIL, 28 de octubre de 2015, Pourvoi n 14-24616, casando una sentencia de la Corte de Apelaciones de Toulouse, de 10 de marzo de 2014. Disponible en: https://www.legifrance.gouv.fr/affichJuriJudi.do?oldAction=rechJuriJudi\&idTexte=JURITEXT00 0031406718\&fastReqld=1072260974\&fastPos $=1$ [visitado el 15 de enero de 2018].

STP SANTIAGO S.A. CON RSA SEgUROS CHILE S.A. (2016): Corte Suprema 30 noviembre 2016 (casación forma y fondo), Rol No 16.929-2016, en: https://suprema.pjud.cl/ [visitado el 23 de noviembre de 2020].

LOYOLA CON ESCUELA ESPECIAL № 9 (2017): Corte de Apelaciones de Temuco 31 mayo 2017 (recurso de nulidad laboral), en: https://corte.pjud.cl/SITCORTEPORTAL/DownloadFile.do?TIP_Documento=3\&TIP_Archivo=3\& COD_Opcion=1\&COD_Corte $=50 \& C R R \_I d T r a m i t e=18384690 \& C R R \_I d D o c u m e n t o=16521975$ [visitado el 23 de noviembre de 2020]. 


\section{NORMAS JURÍDICAS CITADAS}

LEY №18.120, establece normas sobre comparecencia en juicio y modifica los artículos $4^{\circ}$ del Código de Procedimiento Civil y 523 del Código Orgánico de Tribunales. Diario Oficial, 18 de mayo de 1982. 